\title{
IMPLEMENTATION OF ISO 9001 REQUIREMENTS AND THE ECONOMIC EFFICIENCY OF SMALL AND MEDIUM-SIZED ORGANIZATIONS
}

\begin{abstract}
Implementation of ISO 9001, especially for small and medium size organizations is undoubtedly a significant investment. It is, therefore, an important question of its viability. Available literature data suggest a lack of conclusive arguments concerning the implementation of a positive ratio requirements of ISO 9001 to increase the financial efficiency of the organization. So puzzling is the significant popularity of the implementation of system solutions. The article elaborates on the impact of the implementation of ISO 9001 on the economic efficiency of the organization. The overall aim of the research carried out in 2010 was to determine the effects of the implementation of the quality management system according to ISO 9001 on the economic efficiency of small and medium-sized organizations. For this purpose, the analysis of financial statements, and then the compilation of the results of the two groups of organizations were made: the organization with implemented quality management system according to ISO 9001, organizations which decided not to implement of ISO 9001. An important factor in selecting the research group was that the organizations surveyed operate in conditions as close as possible outside and represented one industry. The selection for the organization of such a group would minimize the effect of different external factors on their economic efficiency. As a result of the search 22 companies were selected in the framework of a purchasing group (implementing a common strategy, logistics, marketing and offering a similar range of products).
\end{abstract}

Keywords: quality, management, system, ISO 9001, efficiency

\section{INTRODUCTION}

In economic terms the concept of 'efficiency' is identified with the economic efficiency of business entities, involving the ability of these entities to produce at the time and with the help of a set of resources given amount of goods and services and meet the needs of the recipient. At the same time inseparable features of this performance is a fast and purposeful action. Effectiveness is understood as an exercise of the right things in the right way and can be considered as a measure that takes into account two points of view: internal, focusing on the classical understanding of the issues of productivity and external, taking into account customer feedback on their perceived value.

The article elaborates on the impact of the implementation of ISO 9001 requirements on the economic efficiency of the organization. It should be emphasized that the ISO 9000 standards do not refer to the fulfillment of an objective or the attainment of a determined result. In other words, they are not standards that measure the quality of goods or services of a firm, but rather establish the need to systemise and formalise a series of procedures, a

\footnotetext{
${ }^{1}$ Dr Dominik Zimon, Katedra Systemów Zarządzania i Logistyki, Wydział Zarządzania, Politechnika Rzeszowska, Wydział Zarządzania, Politechnika Rzeszowska im. Ignacego Łukasiewicza, al. Powstańców Warszawy 8 , 35-959 Rzeszów, tel. 17 8651073, e-mail: zdomin@prz.edu.pl.
} 
whole series of business processes: being ISO 9000 compliant means having implemented a QMS that draws together in standardised and documented procedures the basic processes for the production of the good or service that the client purchases ${ }^{2}$. Organizations that implemented the requirements of ISO 9001 receive many tangible benefits ${ }^{3}$. However, there is concern that the implementation of formal quality management system and the significant costs associated with implementation and maintenance of the system can adversely affect the effectiveness of particularly smaller organizations ${ }^{4}$. The overall aim of the research carried out in 2010 was to determine the effects of the implementation of the quality management system according to ISO 9001 on the economic efficiency of small and medium-sized organizations. For this purpose, the analysis of financial statements was made, and then compiled the results of the two groups of organizations:

- the organization with implemented quality management system according to ISO 9001,

- organizations which decided not to implement requirements of ISO 9001.

An important factor in the selection of the research group was that the organizations surveyed operate in conditions as close as possible outside and represent one industry. Selection for the organization of such a group would minimize the effect of different external factors on their economic efficiency. As a result of the search there were selected 22 companies in the framework of a purchasing group (implementing a common strategy, logistics, marketing and offering a similar range of products).

\section{RESULTS AND THEIR ANALYSIS}

The first group of the analyzed indicators were the turnover rates (also called the performance measures). Their basic task is to investigate the efficiency of business processes in the organization and use of its material resources ${ }^{5}$. The most important indicators for this issue include:

- $\quad$ average collection period of receivables,

- current assets turnover.

Average collection period of receivables indicates the time it takes an organization to regulate its own commitments. It is assumed that the higher the level of payables turnover ratio, the organization in a more sluggish way seeks to settle its obligations to customers. Such a situation is for the leadership of the organization very comfortable, but also can affect in a negative way on existing relationships with customers.

\footnotetext{
${ }^{2}$ Heras-Saizarbitoria I., Casadesu' M., Marimo' F.: The impact of ISO 9001 standard and the EFQM model: The view of the assessors, Total Quality Management Vol. 22, No. 2, 2011, p 199.

${ }^{3}$ Zimon D., Sikora T.: Ocena funkcjonowania systemu zarządzanie jakością w małych i średnich organizacjach handlowych, Handel Wewnętrzny, no. 2, 2012, p. 21.

${ }^{4}$ Zimon D.: Ocena efektów wdrożenia wymagań normy ISO $9001 \mathrm{w}$ małych i średnich organizacjach handlowych, Problemy Zarządzania, no. 2, 2012, p. 72.

${ }^{5}$ Grzenkowicz N., Kowalczyk J., Kusak A., Podgórski Z.: Analiza ekonomiczna przedsiębiorstwa, WNWZ, Warszawa 2007, p. 218.
} 
Implementation of ISO 9001 requirements ...

Table 1. Individual sizes of payables turnover rates in organizations that have not implemented the quality management system according to ISO 9001 in the years 2004 to 2008

\begin{tabular}{|c|c|c|c|c|c|c|}
\hline \multirow{2}{*}{ Company } & \multicolumn{5}{|c|}{ Years } & \multirow[t]{2}{*}{ Average Value } \\
\hline & 2004 & 2005 & 2006 & 2007 & 2008 & \\
\hline 1 & 79 & 104 & 164 & 122 & 104 & 114,60 \\
\hline 2 & 101,5 & 91 & 137 & 93 & 140,3 & 112,56 \\
\hline 3 & 144 & 170 & 103 & 151 & 92 & 132,00 \\
\hline 4 & 68 & 79 & 104 & 70 & 64 & 77,00 \\
\hline 5 & 49 & 57 & 55 & 55 & 53 & 53,80 \\
\hline 6 & 84,86 & 97,68 & 97,67 & 71 & 90 & 88,24 \\
\hline 7 & 38,72 & 53,58 & 49,01 & 32,69 & 16,99 & 38,20 \\
\hline 8 & 59,14 & 82 & 70 & 62 & 57 & 66,03 \\
\hline 9 & 63,33 & 89,1 & 83,55 & 58 & 95 & $\mathbf{7 7 , 8 0}$ \\
\hline 10 & 75,25 & 104,83 & 109,47 & 108 & 117 & 102,91 \\
\hline 11 & 94,88 & 115,9 & 141,2 & 123,3 & 142,8 & 123,62 \\
\hline 12 & 81,01 & 98,82 & 122,09 & 122 & 127 & 110,18 \\
\hline 13 & 59,67 & 91,95 & 78,91 & 88 & 89 & 81,51 \\
\hline 14 & 46,17 & 54 & 39 & 47,92 & 47,7 & 46,96 \\
\hline 15 & 44,2 & 49,2 & 63,8 & 52,4 & 86,1 & 59,14 \\
\hline 16 & 49,64 & 50,76 & 49,6 & 33 & 25,9 & 41,78 \\
\hline
\end{tabular}

Source: results of own research

Table 2. Individual sizes of payables turnover rates in organizations with the implemented quality management system according to ISO 9001 in the years 2004 to 2008

\begin{tabular}{|c|c|c|c|c|c|c|}
\hline \multirow{2}{*}{ Company } & \multicolumn{5}{|c|}{ Years } & \multirow[t]{2}{*}{ Average Value } \\
\hline & 2004 & 2005 & 2006 & 2007 & 2008 & \\
\hline 1 & 32,96 & 61,4 & 51,36 & 47 & 31 & 44,74 \\
\hline 2 & 85,95 & 117,87 & 110 & 107 & 96,7 & 103,50 \\
\hline 3 & 64,6 & 89 & 64 & 59 & 60 & 67,32 \\
\hline 4 & 77,8 & 75,2 & 74,8 & 66 & 60 & 70,76 \\
\hline 5 & 93,9 & 122,9 & 123,2 & 121,6 & 102,4 & 112,80 \\
\hline 6 & 86 & 88 & 89,6 & 70 & 83,86 & 83,49 \\
\hline
\end{tabular}

Source: results of own research 
Table 3. Summary of relevant indicators payables turnover in organizations that have not implemented the quality management system according to ISO 9001 in the years 2004 to 2008

\begin{tabular}{|c|c|c|c|c|c|c|}
\hline The level of & 2004 r. & 2005 r. & 2006 r. & 2007 r. & 2008 r. & $\begin{array}{c}\text { Average } \\
\text { Value }\end{array}$ \\
\hline $\begin{array}{l}\text { turnover } \\
\text { ratio in days }\end{array}$ & $\begin{array}{c}\% \text { of } \\
\text { companies }\end{array}$ & $\begin{array}{c}\% \text { of } \\
\text { companies }\end{array}$ & $\begin{array}{c}\% \text { of } \\
\text { companies }\end{array}$ & $\begin{array}{c}\% \text { of com- } \\
\text { panies }\end{array}$ & $\begin{array}{c}\% \text { of com- } \\
\text { panies }\end{array}$ & $\begin{array}{c}\% \text { of com- } \\
\text { panies }\end{array}$ \\
\hline 0 - 30 & 0,00 & 0,00 & 0,00 & 0,00 & 12,50 & 2,50 \\
\hline $31-60$ & 43,75 & 31,25 & 25,00 & 37,50 & 18,75 & 31,25 \\
\hline $61-90$ & 37,50 & 18,75 & 25,00 & 25,00 & 25,00 & 26,25 \\
\hline above 90 & 18,75 & 50,00 & 50,00 & 37,50 & 43,75 & 40,00 \\
\hline
\end{tabular}

Source: results of own research

Table 4. Summary of relevant indicators payables turnover in organizations with the implemented quality management system according to ISO 9001 in the years 2004 to 2008

\begin{tabular}{|c|c|c|c|c|c|c|}
\hline $\begin{array}{c}\text { The level of } \\
\text { payables }\end{array}$ & 2004 r. & 2005 r. & 2006 r. & 2007 r. & 2008 r. & $\begin{array}{l}\text { Average } \\
\text { Value }\end{array}$ \\
\hline $\begin{array}{c}\text { turnover } \\
\text { ratio in days }\end{array}$ & $\begin{array}{c}\% \text { of } \\
\text { companies }\end{array}$ & $\begin{array}{c}\% \text { of } \\
\text { companies }\end{array}$ & $\begin{array}{c}\% \text { of } \\
\text { companies }\end{array}$ & $\begin{array}{l}\% \text { of com- } \\
\text { panies }\end{array}$ & $\begin{array}{l}\% \text { of com- } \\
\text { panies }\end{array}$ & $\begin{array}{c}\% \text { of com- } \\
\text { panies }\end{array}$ \\
\hline 0 - 30 & 0,00 & 0,00 & 0,00 & 0,00 & 0,00 & 0,00 \\
\hline $31-60$ & 16,67 & 0,00 & 16,67 & 33,33 & 50,00 & 23,33 \\
\hline $61-90$ & 66,67 & 66,67 & 50,00 & 33,33 & 16,67 & 46,67 \\
\hline above 90 & 16,67 & 33,33 & 33,33 & 33,33 & 33,33 & 30,00 \\
\hline
\end{tabular}

Source: results of own research

According to W. Szczesny ${ }^{6}$ and co-authors from the point of view of the future of the organization, management should strive to maintain the longest period payables turnover in days. This is due to the fact that the extension of the settlement of liabilities (provided that the organization is not exposed to losses in the form of penalty interest) is an additional and important source of financing free enterprise. According the results of the company, which does not operate a quality management system according to ISO 9001, in $10 \%$ more cases have liabilities turnover exceeding 90 days. At the same time the liabilities turnover in the group is more than $20 \%$ lower in the range of 61 to 90 days than in the group of companies in accordance with the principles of quality management systems standard.

\footnotetext{
${ }^{6}$ Szczęsny W., Śliwa J., Winter M., Wymysłowski S.: Finanse firmy. Jak zarządzać kapitałem, C. H. Beck, Warszawa 2007, p. 281.
} 
Implementation of ISO 9001 requirements ...

With assets of turnover ratio one can provide information on the number of "cycles" of selling any property during the year.

Table 5. Individual sizes of the turnover ratios of current assets in organizations that have not implemented the quality management system according to ISO 9001 in the years 2004 to 2008

\begin{tabular}{|c|c|c|c|c|c|c||}
\hline \multirow{2}{*}{ Company } & \multicolumn{7}{|c|}{ Years } & \multirow{2}{*}{ Average Value } \\
\cline { 2 - 6 } & $\mathbf{2 0 0 4}$ & $\mathbf{2 0 0 5}$ & $\mathbf{2 0 0 6}$ & $\mathbf{2 0 0 7}$ & $\mathbf{2 0 0 8}$ & \\
\hline 1 & 3,79 & 2,9 & 2 & 2 & 2,3 & $\mathbf{2 , 6 0}$ \\
\hline 2 & 4,1 & 4,14 & 2,93 & 3 & 3,2 & $\mathbf{3 , 4 7}$ \\
\hline 3 & 5,8 & 4,3 & 5,3 & 8,3 & 5,5 & $\mathbf{5 , 8 4}$ \\
\hline 4 & 3,5 & 3,5 & 2,2 & 2,6 & 2,8 & $\mathbf{2 , 9 2}$ \\
\hline 5 & 2,23 & 2,21 & 2,3 & 2,17 & 2,6 & $\mathbf{2 , 3 0}$ \\
\hline 6 & 3,09 & 2,88 & 2,85 & 3,48 & 2,68 & $\mathbf{3 , 0 0}$ \\
\hline 7 & 4,52 & 4,03 & 3,99 & 4,63 & 4,79 & $\mathbf{4 , 3 9}$ \\
\hline 8 & 5,49 & 4 & 4,21 & 3,95 & 3,13 & $\mathbf{4 , 1 6}$ \\
\hline 9 & 2,79 & 2 & 1,95 & 2,17 & 1,65 & $\mathbf{2 , 1 1}$ \\
\hline 10 & 3,1 & 2,75 & 2,73 & 2,57 & 2,34 & $\mathbf{2 , 7 0}$ \\
\hline 11 & 2,58 & 2 & 1,84 & 2,04 & 1,85 & $\mathbf{2 , 0 6}$ \\
\hline 12 & 3,24 & 2,6 & 2,2 & 2,21 & 1,92 & $\mathbf{2 , 4 3}$ \\
\hline 13 & 3,89 & 3 & 3,24 & 2,8 & 2,6 & $\mathbf{3 , 1 1}$ \\
\hline 14 & 3,65 & 3,37 & 3,32 & 4,47 & 3,19 & $\mathbf{3 , 6 0}$ \\
\hline 15 & 5,08 & 4,47 & 3,37 & 3,5 & 3 & $\mathbf{3 , 8 8}$ \\
\hline 16 & 5,24 & 4,6 & 4 & 3,95 & 3,8 & $\mathbf{4 , 3 2}$ \\
\hline
\end{tabular}

Source: results of own research

Table 6. Individual sizes of the turnover ratios of current assets in organizations with implemented a quality management system according to ISO 9001 in the years 2004 to 2008

\begin{tabular}{|c|c|c|c|c|c|c||}
\hline \hline \multirow{2}{*}{ Company } & \multicolumn{7}{|c|}{ Years } & \multirow{2}{*}{ Average Value } \\
\cline { 2 - 6 } & $\mathbf{2 0 0 4}$ & $\mathbf{2 0 0 5}$ & $\mathbf{2 0 0 6}$ & $\mathbf{2 0 0 7}$ & $\mathbf{2 0 0 8}$ & \\
\hline 1 & 4,63 & 3,15 & 3,29 & 3,3 & 3,52 & $\mathbf{3 , 5 8}$ \\
\hline 2 & 3,14 & 2,43 & 2,6 & 2,4 & 2,6 & $\mathbf{2 , 6 3}$ \\
\hline 3 & 3,33 & 2,27 & 2,41 & 3,8 & 3,17 & $\mathbf{3 , 0 0}$ \\
\hline 4 & 3,68 & 4 & 3,61 & 3,5 & 3,3 & $\mathbf{3 , 6 2}$ \\
\hline 5 & 2,98 & 2,88 & 2,69 & 2,99 & 3,45 & $\mathbf{3 , 0 0}$ \\
\hline 6 & 3,18 & 3,11 & 2,8 & 3,8 & 2,5 & $\mathbf{3 , 0 8}$ \\
\hline
\end{tabular}

Source: results of own research 
Table 7. Summary of sizes of the turnover ratios of current assets in organizations that have not implemented the quality management system according to ISO 9001 above 2004 - 2008

\begin{tabular}{|c|c|c|c|c|c|c||}
\hline $\begin{array}{c}\text { The level of } \\
\text { current } \\
\text { assets turn- } \\
\text { over ratio }\end{array}$ & \begin{tabular}{c}
$\mathbf{2 0 0 4}$ \\
\cline { 2 - 7 }
\end{tabular} & $\mathbf{2 0 0 5}$ & $\mathbf{2 0 0 6}$ & $\mathbf{2 0 0 7}$ & $\mathbf{2 0 0 8}$ & $\begin{array}{c}\text { Average } \\
\text { Value }\end{array}$ \\
\hline $\mathbf{0 - 2}$ & 0,00 & 12,50 & 18,75 & 6,25 & 18,75 & $\mathbf{1 1 , 2 5}$ \\
\hline $\mathbf{2 , 1 - 4}$ & 62,50 & 56,25 & 68,75 & 75,00 & 68,75 & $\mathbf{6 6 , 2 5}$ \\
\hline $\mathbf{4 , 1 - 6}$ & 37,50 & 31,25 & 12,50 & 12,50 & 12,50 & $\mathbf{2 1 , 2 5}$ \\
\hline panies & $\begin{array}{c}\text { \% of com- } \\
\text { panies }\end{array}$ & $\begin{array}{c}\text { \% of com- } \\
\text { panies }\end{array}$ & $\begin{array}{c}\text { \% of com- } \\
\text { panies }\end{array}$ & $\begin{array}{c}\text { \% of com- } \\
\text { panies }\end{array}$ \\
\hline Powyżej 6 & 0,00 & 0,00 & 0,00 & 6,25 & 0,00 & $\mathbf{1 , 2 5}$ \\
\hline
\end{tabular}

Source: results of own research

Table 8 Summary of sizes of the turnover ratios of current assets in the organization of the implemented quality management system according to ISO 9001 in the years 2004 to 2008

\begin{tabular}{|c|c|c|c|c|c|c||}
\hline $\begin{array}{c}\text { The level of } \\
\text { current } \\
\text { assets turn- } \\
\text { over ratio }\end{array}$ & $\mathbf{2 0 0 4}$ & $\mathbf{2 0 0 5}$ & $\mathbf{2 0 0 6}$ & $\mathbf{2 0 0 7}$ & $\mathbf{2 0 0 8}$ & $\begin{array}{c}\text { Average } \\
\text { Value }\end{array}$ \\
\cline { 2 - 7 } & panies & $\begin{array}{c}\text { \% of com- } \\
\text { panies }\end{array}$ & $\begin{array}{c}\text { \% of com- } \\
\text { panies }\end{array}$ & $\begin{array}{c}\% \text { of com- } \\
\text { panies }\end{array}$ & $\begin{array}{c}\% \text { of com- } \\
\text { panies }\end{array}$ & $\begin{array}{c}\text { \% of com- } \\
\text { panies }\end{array}$ \\
\hline $\mathbf{0 ~ - \mathbf { 2 }}$ & 0,00 & 0,00 & 0,00 & 0,00 & 0,00 & $\mathbf{0 , 0 0}$ \\
\hline $\mathbf{2 , 1}-\mathbf{4}$ & 83,33 & 100,00 & 100,00 & 100,00 & 100,00 & $\mathbf{9 6 , 6 7}$ \\
\hline $\mathbf{4 , 1}-\mathbf{6}$ & 16,67 & 0,00 & 0,00 & 0,00 & 0,00 & $\mathbf{3 , 3 3}$ \\
\hline Above 6 & 0,00 & 0,00 & 0,00 & 0,00 & 0,00 & $\mathbf{0 , 0 0}$ \\
\hline
\end{tabular}

Source: results of own research

Decomposition of the results indicates that the vast majority of organizations with implemented a quality management system (over 96\%) the amount of current assets turnover ratio is in the range from 2.1 to 4 .

Different results were noted in the second group of companies, in which more than $30 \%$ fewer companies ranked in the same range. This range can be considered as the most optimal, according to T. and M. Sierpińska Jachna the turnover level of assets should not be too high, as this may lead to disequilibrium in rhythmic continuity of production and sales and the deterioration of the degree of capacity utilization as a result of inventory shortages result of inventory shortages. But also it can't be too low because it leads to freezing of working capital as current assets. To complete the carried out it was also examined the debt level of the organizations. Any company in order to function properly and achieve ever higher goals uses a different sources of funding (both own and foreign, and short and long term). When assessing the level of debt of the company it can be said that it has a type and source of financing assets. This knowledge allows to choose the optimal 
debt strategies taking into account the level of risk the organization and functioning of the financial stability of the company. For this purpose, can be applied many of the indicators included in the area of financial support for the publication of selected:

- The ratio of total liabilities to equity (debt to equity ratio).

The last of these indicators designed to analysis of the financial support is the so-called debt to equity ratio. It is instrumental in assessing the size of the outside capital used in relation to equity. This relationship is expressed by the equation:

\section{Debt to Equity Ratio = Total Liabilities / Total Equity}

It is not desirable when the level of this ratio significantly exceeds $\mathbf{1 . 0}$, because it indicates a low level of equity in the organization.

Table 9. Summary of the relationship of debt to equity indicators showing commitments to equity in the financing of assets in organizations that have not implemented the Quality Management System according to ISO 9001 in $2004-2008$

\begin{tabular}{||l|c|c|c|c|c|c||}
\hline \multirow{2}{*}{$\begin{array}{l}\text { Relationship } \\
\text { of Debt to } \\
\text { Equity }\end{array}$} & $\mathbf{2 0 0 4}$ & $\mathbf{2 0 0 5}$ & $\mathbf{2 0 0 6}$ & $\mathbf{2 0 0 7}$ & $\mathbf{2 0 0 8}$ & $\begin{array}{c}\text { Average } \\
\text { Value }\end{array}$ \\
\cline { 2 - 7 } & $\begin{array}{c}\text { \% of com- } \\
\text { panies }\end{array}$ & $\begin{array}{c}\text { \% of com- } \\
\text { panies }\end{array}$ & $\begin{array}{c}\text { \% of com- } \\
\text { panies }\end{array}$ & $\begin{array}{c}\text { \% of com- } \\
\text { panies }\end{array}$ & $\begin{array}{c}\text { \% of com- } \\
\text { panies }\end{array}$ & $\begin{array}{c}\text { \% of com- } \\
\text { panies }\end{array}$ \\
\hline $\begin{array}{l}\text { Less than } \\
\mathbf{0 . 8}\end{array}$ & 6.25 & 6.25 & 12.50 & 12.50 & 31.25 & $\mathbf{1 3 . 7 5}$ \\
\hline $\mathbf{0 . 8}-\mathbf{1 . 2}$ & 18.75 & 12.50 & 6.25 & 25.00 & 12.50 & $\mathbf{1 5 . 0 0}$ \\
\hline $\mathbf{1 . 2 1 - 1 . 5}$ & 12.50 & 18.75 & 18.75 & 12.50 & 6.25 & $\mathbf{1 3 . 7 5}$ \\
\hline $\mathbf{1 . 5 1 - \mathbf { 2 . 0 }}$ & 18.75 & 18.75 & 25.00 & 31.25 & 25.00 & $\mathbf{2 3 . 7 5}$ \\
\hline $\begin{array}{l}\text { more than } \\
\mathbf{2 . 0}\end{array}$ & 43.75 & 43.75 & 37.50 & 18.75 & 25.00 & $\mathbf{3 3 . 7 5}$ \\
\hline
\end{tabular}

Source: results of own research 
Table 10 Summary of the relationship of debt to equity indicators showing commitments to equity in the financing of assets in the organization that implemented Quality Management System according to ISO 9001 in $2004-2008$

\begin{tabular}{|l|c|c|c|c|c|c|}
\hline $\begin{array}{l}\text { Relationship } \\
\text { of Debt to } \\
\text { Equity }\end{array}$ & $\mathbf{2 0 0 4}$ & $\mathbf{2 0 0 5}$ & $\mathbf{2 0 0 6}$ & $\mathbf{2 0 0 7}$ & $\mathbf{2 0 0 8}$ & $\begin{array}{c}\text { Average } \\
\text { Value }\end{array}$ \\
\cline { 2 - 7 } & $\begin{array}{c}\text { \% of com- } \\
\text { panies }\end{array}$ & $\begin{array}{c}\text { \% of com- } \\
\text { panies }\end{array}$ & $\begin{array}{c}\text { \% of com- } \\
\text { panies }\end{array}$ & $\begin{array}{c}\text { \% of com- } \\
\text { panies }\end{array}$ & $\begin{array}{c}\text { \% of com- } \\
\text { panies }\end{array}$ & $\begin{array}{c}\text { \% of com- } \\
\text { panies }\end{array}$ \\
\hline $\begin{array}{l}\text { Less than } \\
\mathbf{0 . 8}\end{array}$ & 33.33 & 16.67 & 33.33 & 33.33 & 33.33 & $\mathbf{3 0 . 0 0}$ \\
\hline $\mathbf{0 . 8 - 1 . 2}$ & 0.00 & 16.67 & 0.00 & 0.00 & 33.33 & $\mathbf{1 0 . 0 0}$ \\
\hline $\mathbf{1 . 2 1 - 1 . 5}$ & 16.67 & 0.00 & 0.00 & 16.67 & 0.00 & $\mathbf{6 . 6 7}$ \\
\hline $\mathbf{1 . 5 1 - 2 . 0}$ & 0.00 & 0.00 & 0.00 & 16.67 & 0.00 & $\mathbf{3 . 3 3}$ \\
\hline $\begin{array}{l}\text { more than } \\
\mathbf{2 . 0}\end{array}$ & 50.00 & 66.67 & 66.67 & 33.33 & 33.33 & $\mathbf{5 0 . 0 0}$ \\
\hline
\end{tabular}

Source: results of own research

As in the previous case, the company adhering to the requirements of ISO 9001 in a larger number of cases has shown an optimal level of debt to equity. Exactly $30 \%$ of them outweigh the level of outside financed equity, which puts the company in a privileged position in relation to other organizations (and this result is $16.25 \%$ better than in the group not complying with the requirements of ISO 9001).

\section{CONCLUSIONS}

When analyzing the economic efficiency of organizations associated in individual groups there can be concluded positive results of standardized implementation of quality management systems in the financial condition of the organization because:

- enterprises that apply to the requirements of ISO 9001 have shown a more optimal level of payables turnover ratio. In addition, over $30 \%$ of cases are less exposed to continuous sales disturbance (too high the turnover of current assets)

- organizations that implemented a quality management system according to ISO 9001 in a large number of cases have shown a more optimal ratio relationship commitment to equity. The dangerous dominance of outside capital over their own (index level above 1.51) in both groups is spotted at similar number of companies.

\section{REFERENCES}

[1] Grzenkowicz N., Kowalczyk J., Kusak A., Podgórski Z.: Analiza ekonomiczna przedsiębiorstwa, WNWZ, Warszawa 2007.

[2] Heras-Saizarbitoria I., Casadesu' M., Marimo' F.: The impact of ISO 9001 standard and the EFQM model: The view of the assessors, Total Quality Management Vol. 22, No. 2, 2011. 
[3] Szczęsny W., Śliwa J., Winter M., Wymysłowski S.: Finanse firmy. Jak zarządzać kapitałem, C. H. Beck, Warszawa 2007.

[4] Zimon D., Sikora T.: Ocena funkcjonowania systemu zarządzanie jakością w małych i średnich organizacjach handlowych, Handel Wewnętrzny, nr 2, 2012, s. 21.

[5] Zimon D.: Ocena efektów wdrożenia wymagań normy ISO $9001 \mathrm{w}$ małych i średnich organizacjach handlowych, Problemy Zarządzania, nr 2, 2012, s. 72.

\section{IMPLEMENTACJA WYMAGAŃ NORMY ISO 9001 A EFEK- TYWNOŚĆ EKONOMICZNA MAŁYCH I ŚREDNICH ORGANIZACJI}

Wdrażanie wymagań systemu zarządzania jakością według normy ISO 9001 jest bezsprzecznie inwestycją. Zasadne staję się pytanie o jej opłacalność. Analiza literatury przedmiotu nie dostarcza przekonywujących informacji dotyczących pozytywnego przełożenia implementacji systemu zarządzania jakością według wymagań normy ISO 9001 na efektywność ekonomiczną małych i średnich organizacji. Zastanawiające jest, więc znaczna popularność implementacji wymagań systemowych w przedsiębiorstwach. W artykule podjęto rozważania na temat wpływu implementacji wymagań normy ISO 9001 na efektywność ekonomiczną małych i średnich organizacji. Nadrzędnym celem badań przeprowadzonych w 2010 roku była próba ustalenia wpływu wdrożenia systemu zarządzania jakością według normy ISO 9001 na efektywność ekonomiczną małych i średnich organizacji. W tym celu dokonano analizy sprawozdań finansowych, a następnie zestawienia wyników dwóch grup organizacji: organizacji z wdrożonym systemem zarządzania jakością według normy ISO 9001, organizacji w których nie zdecydowano się na implementacje wymagań normy ISO 9001. Istotnym czynnikiem doboru grupy badawczej było to, aby badane organizacje funkcjonowały w jak najbardziej zbliżonych warunkach zewnętrznych i reprezentowały jedną branże. Wyselekcjonowanie takiej grupy organizacji pozwoliłoby zminimalizować wpływ odmiennych czynników zewnętrznych na ich efektywność ekonomiczna. W wyniku poszukiwań wybrano 22 przedsiębiorstwa zrzeszone w ramach jednej grupy zakupowej (realizujące wspólną strategię, logistykę, działania marketingowe oraz oferujące podobny asortyment produktów). Wyniki przeprowadzonych badań pozwoliły udzielić odpowiedzi na postawione pytania badawcze.

Słowa kluczowe: jakość, zarządzanie, system, ISO 9001, efektywność

DOI: $10.7862 /$ rz.2013.mmr.65

Tekst złożono w redakcji: wrzesień 2013

Przyjęto do druku: grudzień 2013 